\title{
Metode Deteksi Kandungan Babi dan Alkohol dalam Eksipien Farmasi dan Produk Obat untuk Menjamin Kehalalan Sediaan Obat
}

Patihul Husni*, Norisca Aliza Putriana, Imam Adi Wicaksono Departemen Farmasetika dan Teknologi Farmasi, Fakultas Farmasi Universitas Padjadjaran, 45363, Indonesia *email: patihul.husni@unpad.ac.id

\section{ABSTRAK}

Bagi seorang muslim, status halal suatu produk obat dan eksipien yang digunakan adalah hal mutlak harus dipenuhi. Produk obat halal tersebut harus bebas dari kandungan babi dan alkohol baik dari bahan dasamya maupun proses pembuatannya. Pentingnya metode untuk mendeteksi kandungan babi dan alkohol untuk memastikan suatu produk obat bebas dari kandungan babi dan alkohol menjadi latar belakang review artikel ini. Metode review artikel ini adalah mengumpulkan literatur yang berkaitan dengan metode deteksi kandungan babi dan alkohol/etanol dan membuat ringkasan dari literatur-literatur tersebut. Hasil review menunjukkan bahwa metode deteksi yang dapat digunakan yaitu metode analisis PDK (Pork Detection Kit) untuk mendeteksi protein babi, metode PCR (Polymerase Chain Reaction) untuk mendeteksi DNA babi dan metode GC (Gas Chromatography) atau HPLC (High Performance Liquid Chromatography) untuk mendeteksi residu alkohol/etanol.

Kata Kunci: Halal, Babi, Alkohol, Eksipien Farmasi, Produk Obat

\section{PENDAHULUAN}

Status halal sudah menjadi suatu isu global. Tak terkecuali untuk produk obat dan eksipien farmasi yang digunakan. Obat-obatan yang beredar di tengah masyarakat diduga banyak yang tidak halal. Ketidakhalalan tersebut dapat bersumber dari bahan dasarnya maupun proses pembuatannya. Data LPPOM MUI menunjukkan bahwa sampai saat ini baru 34 jenis obat yang memiliki sertifikat halal dari 30 ribuan jenis obat yang beredar dimasyarakat. Minimnya obat bersertifikat halal tersebut membuktikan bahwa kepedulian industri obat dan masyarakat pengguna obat hampir-hampir tak peduli dengan persoalan halal-haram obat. Ketidakpedulian masyarakat akan kehalalan dan keharaman obat disebabkan hukum kedaruratan demi kemanusiaan. ${ }^{1}$

Obat halal harus memenuhi persyaratan tertentu diantaranya bahannya tidak boleh berasal dari babi dan derivatnya, tidak mengandung alkohol, tidak beracun dan tidak berbahaya bagi tubuh, bebas dari bahan kotor atau najis, tidak menimbulkan efek berbahaya dikemudian hari, dan tidak boleh mengandung organ tubuh manusia, ari-ari dan air seni.2, 3, 4,5 Oleh karena itu, produk obat benar-benar harus memenuhi kriteria obat halal dan dipastikan tidak menggunakan atau mengandung bahan-bahan tersebut. 
Pada umumnya yang menjadi sorotan adalah sediaan obat harus benar-benar bebas dari kandungan babi dan alkohol baik bahan aktif dan eksipien yang digunakan, proses pembuatannya maupun produk akhir sediaan obatnya. Salah satu cara untuk mengotentikasi kehalalan produk makanan dan farmasi adalah analisis kimia yang didasarkan untuk menemukan penanda spesifik. Beberapa teknik analisis telah diusulkan dan terus dikembangkan untuk otentikasi produk halal. ${ }^{4}$

Pentingnya suatu produk obat bebas dari kandungan babi dan alkohol harus diyakinkan dengan suatu metode pendeteksiannya. Hal inilah yang menjadi latar belakang pembuatan review artikel ini yang menitikberatkan pada pembahasan mengenai metode yang dapat digunakan untuk mendeteksi kandungan babi dan alkohol dalam eksipien farmasi dan produk obat terkait dengan status halal sediaan obat.

\section{METODE}

Peneliti menggunakan sumber data primer yang langsung dikumpulkan oleh peneliti untuk dilakukan review. Pencarian data primer dilakukan dengan instrumen pencari secara online menggunakan Google, dan Google scholar. Pencarian dilakukan dengan menggunakan kata kata kunci "halal", "deteksi babi dan alkohol" dan "metode deteksi kehalalan". Penelusuran lebih lanjut dilakukan secara manual pada pustaka yang relevan. Pustaka yang diinklusi yaitu pustaka yang melakukan penelitian dan atau pemaparan tentang halal dan atau metode deteksi babi dan alkohol terkait status halal baik pustaka nasional maupun internasional.

\section{HASIL DAN PEMBAHASAN}

\section{Kriteria Obat Halal ${ }^{2}$}

Obat halal harus memenuhi kriteria yaitu: 1) Bahan tidak boleh bersumber dari daging babi atau yang tidak disembelih sesuai syariat islam, tidak beracun dan tidak berbahaya bagi tubuh, 2) Seluruh proses pembuatan obat harus bebas dari bahan kotor atau najis, 3) Penggunaan obat tidak menimbulkan efek berbahaya dikemudian hari, dan 4) Setiap komponen yang terlibat dalam pembuatan obat harus harus bersih, bebas kotoran dan najis.

Bahan Obat Yang Tidak Halal

Menurut agama islam, bahan obat yang mengandung babi, alkohol, organ tubuh manusia, ari-ari, air seni dan hewan yang tidak disembelih menurut aturan islam adalah haram. ${ }^{2,6}$ Oleh karena itu, eksipien yang digunakan dalam produk obat benar-benar harus dipastikan tidak menggunakan atau mengandung bahan-bahan tersebut dalam proses pembuatan maupun produk akhir sediaan obatnya.

Bahan yang berasal dari babi dan hewan yang tidak disembelih menurut aturan islam dinyatakan secara jelas statusnya adalah haram. Alkohol, menunut fatwa MUI, dibedakan menjadi alkohol dari industri khamar yang hukumnya adalah haram dan najis dan alkohol non industri khamar yang jika digunakan sebagai bahan tambahan dan tidak terdeteksi dalam produk akhir, maka boleh digunakan dan tidak bemajis. Penggunaan alkohol hasil industri khamar untuk produk makanan, minuman, kosmetika, dan obat-obatan hukumnya haram. Sedangkan penggunaan alkohol hasil industri non khamar untuk proses produksi produk makanan, minuman, kosmetika, dan obat-obatan, hukumnya mubah apabila secara medis tidak membahayakan. ${ }^{3}$ 
Bahan aktif yang berasal dari manusia sering digunakan dalam industri farmasi dan produk obat misalnya keratin rambut manusia untuk pembentukan sistein, plasenta manusia untuk obat luka bakar dan ari-ari atau plasenta untuk obat leukemia, kanker, kelainan darah, stroke, liver hingga diabetes dan jantung. ${ }^{5}$

\section{Metode-metode Deteksi Kandungan Babi dan Alkohol}

SURAT KEPUTUSAN LEMBAGA PENGKAJIAN PANGAN, OBAT-OBATAN DAN KOSMETIKA MAJELIS ULAMA INDONESIA Nomor : SK49/Dir/LPPOM MUI/XII/14 Tentang KEBIJAKAN ANALISA LABORATORIUM menyatakan bahwa beberapa produk termasuk sediaan obat dan eksipien yang digunakan dalam pembuatan obat wajib dilakukan analisa laboratorium dengan target uji berupa protein babi atau DNA babi atau residu etanol pada saat proses sertifikasi oleh LPPOM MUI seperti terlihat pada Tabel 1. Protein babi diperiksa dengan metode analisa PDK (Pork Detection Kit), DNA babi diperiksa dengan metode PCR (Polymerase Chain Reaction), dan residu etanol diperiksa dengan metode GC (Gas Chromatography). ${ }^{7}$

Tabel 1. Target uji beberapa produk ${ }^{7}$

\begin{tabular}{|c|c|c|c|}
\hline No & Produk & Target uji & $\begin{array}{c}\text { Sampel yang } \\
\text { diambil }\end{array}$ \\
\hline 1 & $\begin{array}{l}\text { Produk protein hewani serta produk yang } \\
\text { mengandung daging segar atau daging olahan, } \\
\text { misalnya nugget, roti, abon, risoles daging, } \\
\text { bumbu instan rasa sapi }\end{array}$ & $\begin{array}{l}\text { Protein } \\
\text { babi }\end{array}$ & Produk akhir \\
\hline 2 & $\begin{array}{l}\text { Menu restoran/katering/dapur yang mengandung } \\
\text { daging segar atau daging olahan }\end{array}$ & $\begin{array}{l}\text { Protein } \\
\text { babi }\end{array}$ & $\begin{array}{l}\text { Bahan baku } \\
\text { (daging } \\
\text { segar, } \\
\text { daging } \\
\text { olahan) }\end{array}$ \\
\hline 3 & Produk gelatin & DNAbabi & Produk akhir \\
\hline 4 & $\begin{array}{l}\text { Produk yang mengandung gelatin, contoh kapsul, } \\
\text { coklat, perrnen, cake, vitamin, obat, resin, } \\
\text { kosmetik }\end{array}$ & DNA babi & $\begin{array}{l}\text { Bahan baku } \\
\text { (gelatin) }\end{array}$ \\
\hline 5 & Produk obat yang mengandung enzim & DNAbabi & Produk akhir \\
\hline 6 & $\begin{array}{l}\text { Produk yang diproduksi dengan bahan penolong } \\
\text { etanol yang secara perhitungan diduga kadar } \\
\text { etanol akhir } \geq 1 \% \text {, contoh ekstrak tanaman, flavor }\end{array}$ & $\begin{array}{l}\text { Residu } \\
\text { etanol }\end{array}$ & Produk akhir \\
\hline 7 & $\begin{array}{l}\text { Produk yang dicurigai mengandung etanol, } \\
\text { contoh } \\
\text { minuman, jamu, obat }\end{array}$ & $\begin{array}{l}\text { Residu } \\
\text { etanol }\end{array}$ & Produk akhir \\
\hline
\end{tabular}

\section{Metode Deteksi Spesifik Spesies Untuk Penentuan Kandungan Babi}

Teknologi deteksi spesifik spesies dapat dilakukan menggunakan metode berbasis protein maupun metode berbasis DNA. Metode berbasis DNA memberikan hasil yang lebih sensitif dan spesifik dibandingkan dengan metode berbasis protein. ${ }^{8}$ 


\section{Metode Berbas is Protein}

Metode berbasis protein yang dapat digunakan seperti enzime linked immunosorbent assay (ELISA), SDS PAGE dan rapid kit (Porcine Detection Kit) berbasis ikatan antibodi-antigen.8, 9 Kelemahan metode berbasis protein adalah sifat protein yang tidak stabil terhadap panas dan perlakuan lain pada proses produksi. ${ }^{8}$

Salah satu Pork Detection Test/Porcine Test yang tersedia dipasaran adalah Xema Rapid Test dimana pengujian kandungan babi terhadap sampel makanan, minuman, alat pemotong, maupun fasilitas produksi lainnya sangat mudah dilakukan dan hasil pengujian bisa didapatkan hanya dalam beberapa menit (5-10 menit). Tingkat akurasi hingga $0,1 \%$ atau setara dengan $5-10$ miligram antigen babi/kilogram (5-10 ppm).

Pork Detection Test/Porcine Test merupakan uji cepat immunochromatograhic (lateral flow) yang digunakan untuk pengujian kualitatif atau semi-kuantitatif penentuan antigen daging babi. Antigen dari sampel terikat oleh antibodi yang sangat spesifik melekat pada warna partikel mikro yang kemudian mengalir ke garis tes dan bercampur dengan antibodi babi hingga membentuk garis berwama yang menunjukkan hasil positif.10 Prosedur pengujian dan interpretasi hasil ditunjukkan pada gambar 1 dan gambar 2 .
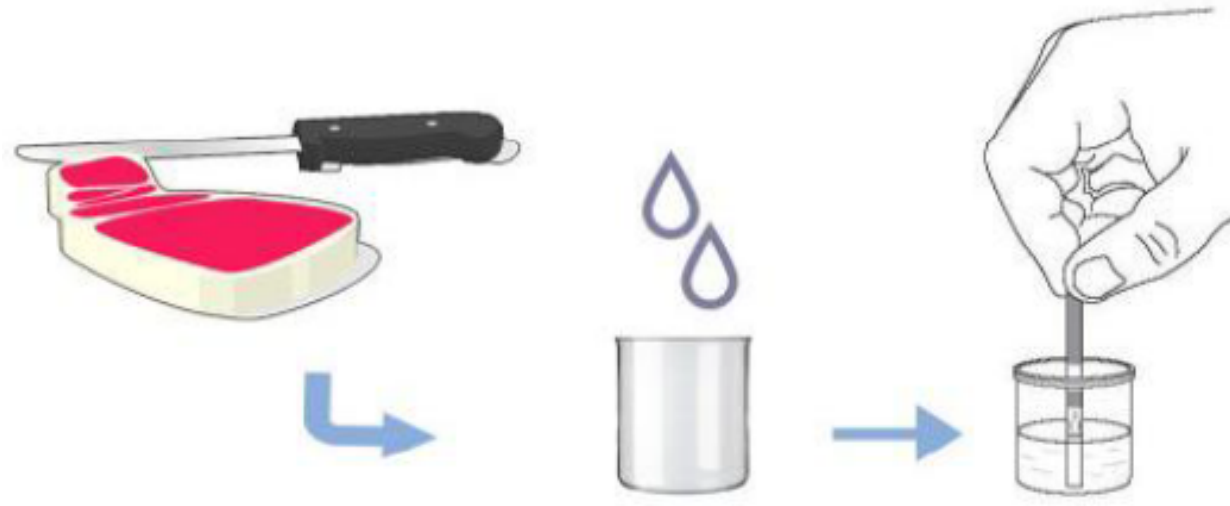

Gambar 1. Prosedur pengujian menggunakan Pork Detection Test/Porcine Test ${ }^{10}$

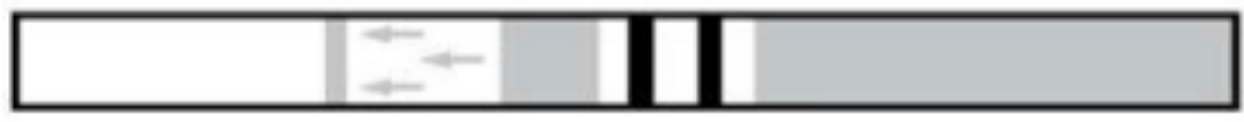

(a) Positif

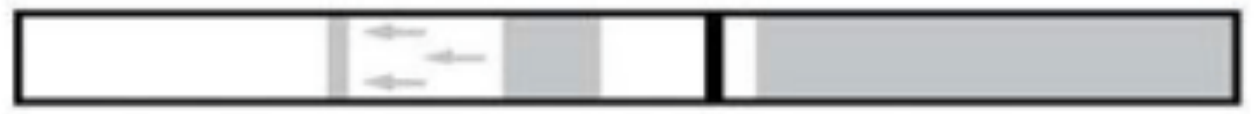

(b) Negatif

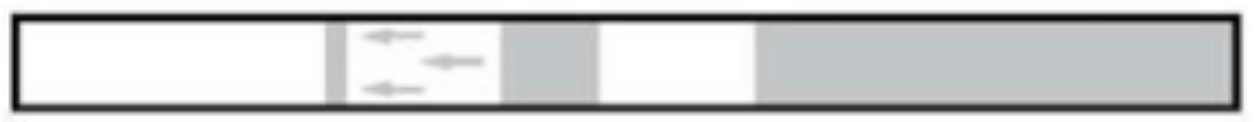

(c) Invalid

Gambar 2.Interpretasi hasil pengujian menggunakan Pork Detection Test/Porcine Test ${ }^{10}$ 


\section{Metode Berbasis DNA}

Metode berbasis DNA umumnya lebih spesifik dan sensitif. Spesifik karena setiap spesies memiliki fragmen sekuen DNA yang conseve dapat menjadi DNA penanda/marker. Sensitif karena mampu mendeteksi DNA dalam jumlah yang sangat sedikit melalui proses amplifikasi DNA. Kandungan DNA spesifik spesies masih dapat dideteksi meskipun produknya telah mengalami proses pengolahan yang kompleks karena sifat DNA yang tahan panas. ${ }^{8}$

Teknologi analisis DNA diantaranya teknologi amplifikasi DNA menggunakan PCR, Real Time PCR, Digital PCR serta LAMP (Loop mediated isothermal amplification), hibridisasi DNA, sequensing DNA dan microarray DNA. ${ }^{8,9}$ Metode PCR banyak digunakan untuk mendeteksi DNA spesifik spesies tertentu seperti spesifik porcine (babi), bovine (sapi), ovine (domba) atau bahkan spesifik manusia. Metode PCR adalah metode amplifikasi urutan fragmen DNA tertentu secara in-vitro menggunakan sepasang primer (oligonukleotida) yang komplementer dengan urutan cetakan DNA tertentu dengan bantuan enzim DNA polymerase..$^{8,11,12}$

Tiga tahap utama dalam PCR yaitu: 1) Ekstraksi DNA (isolasi DNA dani dalam sel atau matriks sampel dan dipurifikasi untuk menghilangkan pengotor atau kontaminan DNA), 2) Amplifikasi DNA (perbanyakan fragmen DNA yang menjadi penanda yang unik bagi spesies yang dideteksi menggunakan primer DNA target), dan 3) Analisis post-PCR (analisis hasil amplifikasi PCR dengan membaca chart pada mesin Realtime PCR atau analisis menggunakan gel elektroforesis pada endpoint PCR. $8,11,12$ Contoh hasil analisis post-PCR menggunakan gel elektroforesis dapat dilihat pada Gambar 3.

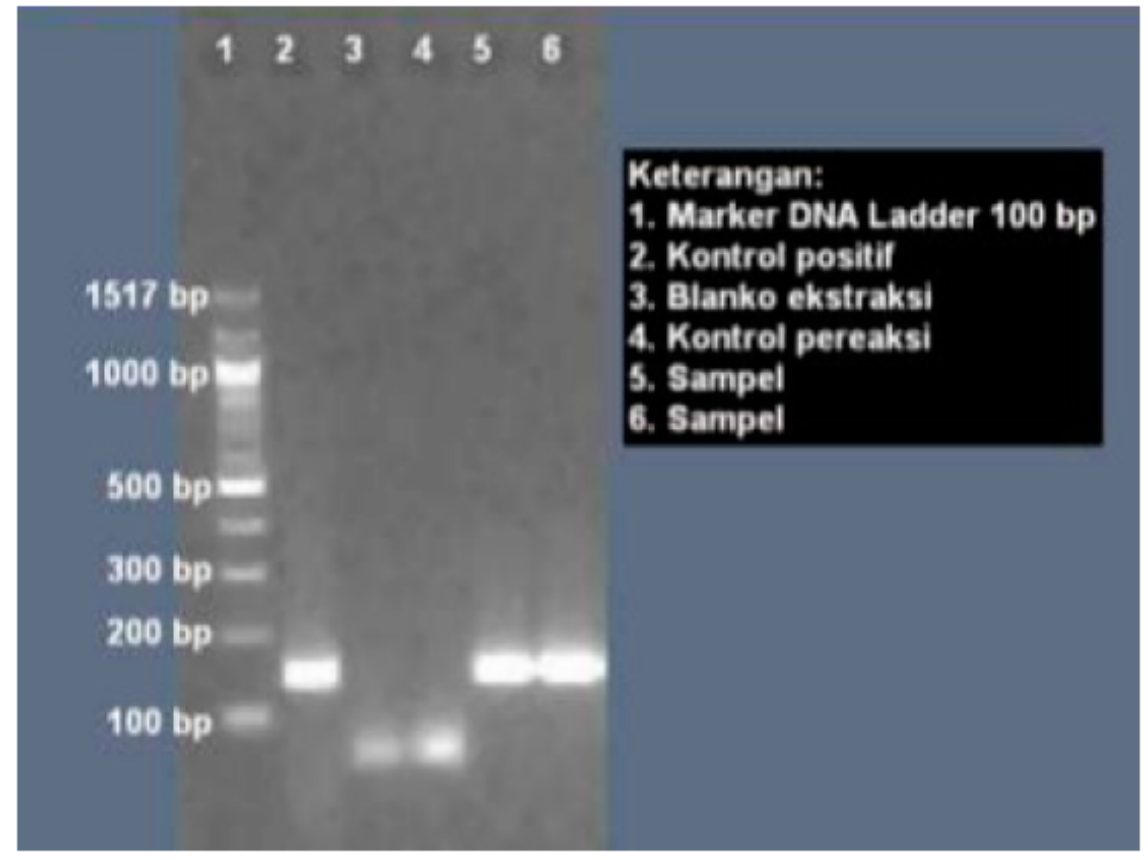

Gambar 3. Hasil analisis post-PCR menggunakan gel elektroforesis. Sampel no. 5 dan 6 mengandung fragmen DNA spesifik babi karena memberikan pita yang sejajar dengan kontrol positif. ${ }^{8}$ 
Residu alkohol/etanol diperiksa dengan metode GC (Gas Chromatography) atau HPLC (High Performance Liquid Chromatography). ${ }^{7} 9$ Sampel diambil jika perusahaan belum memiliki hasil analisa residu etanol menggunakan GC dengan limit deteksi minimal 20 ppm. ${ }^{7}$

Analisis kadar alkohol/etanol dapat dilakukan menggunakan GC yang dilengkapi dengan detektor flame ionization (FID) dan software yang terintegrasi dengan komputer. Suhu detektor FID diatur $150^{\circ} \mathrm{C}$ dan suhu injection port diatur $250^{\circ} \mathrm{C}$. Helium digunakan sebagai gas pembawa dan digunakan dengan flow rate $3^{\circ} \mathrm{C} /$ menit. Kolom kapiler yang digunakan adalah SGE ID-BP20, 30 $\mathrm{m}$, dan diameter $0,25 \mathrm{~mm}$. Suhu oven diatur sebesar $60^{\circ} \mathrm{C}$ pada saat awal, diitingkatkan hingga $80^{\circ} \mathrm{C}$ dan diprogram $20^{\circ} \mathrm{C} /$ menit. $^{13}$

Pada produk makanan, batas penerimaan residu etanol yang ditetapkan adalah berbeda untuk berbagai negara dan organisasi. Secara umum residu etanol sebesar $0,5 \%$ diperbolehkan dalam produk makanan. Namun, Islamic Food and Nutrition Council of America menetapkan kadar alkohol yang diperbolehkan sebesar $0,1 \% .^{13}$

\section{KESIMPULAN}

Bagi seorang muslim, status halal suatu produk obat dan eksipien yang digunakan adalah hal mutlak harus dipenuhi. Produk obat dan eksipien yang digunakan harus bebas dari kandungan babi dan alkohol/etanol yang harus dipastikan dengan suatu metode deteksi karena terkait dengan status halal sediaan obat. Metode deteksi yang dapat digunakan yaitu metode analisis PDK (Pork Detection Kit) untuk mendeteksi protein babi, metode PCR (Polymerase Chain Reaction) untuk mendeteksi DNA babi dan metode GC (Gas Chromatography) atau HPLC (High Performance Liquid Chromatography) untuk mendeteksi residu etanol.

\section{DAFTAR PUSTAKA}

"Obat-obatan banyak tidak halal". http://poskotanews.com/2013/05/23/obat-obatan-banyak-tidakhalal/ [diakses tanggal 2 Juli 2017]

Asmak, A., Fatimah, S., Huzaimah, I., Khuriah, A.H., and Khadijah, A.M.S. 2015. Is Our Medicine Lawful (Halal)?. Middle-East Journal of Scientific Research 23 (3): 367-373

"Hukum Alkohol". http://www.halalmui.org/mui14/index.php/main/detil page/48/2242 [diakses tanggal 2 Juli 2017]

Mursyidi, A. 2013. The Role of Chemical Analysis in the Halal Authentication of Food and Pharmaceutical Products. J. Food Pharm. Sci. 1: 1-4

Keputusan Fatwa Musyawarah Nasional VI Majelis Ulama Indonesia Nomor: 2/MUNAS VI/MUI/2000 Tentang Penggunaan Organ Tubuh, Ari-ari, Air Seni Manusia Bagi Kepentingan Obat-obatan dan Kosmetika. 266-269

Putriana, N.A. 2016. Apakah Obat yang Kita Konsumsi Saat Ini Sudah Halal?. Majalah Farmasetika. Vol. 1 No. 4: 12-14

Surat Keputusan Lembaga Pengkajian Pangan, Obat-obatan dan Kosmetika Majelis Ulama Indonesia Nomor: SK49/Dir/LPPOM MUI/XII/14 Tentang Kebijakan Analisa Laboratorium. 1-4 Pusat Pengujian Obat dan Makanan Nasional Badan POM. 2017. Teknologi Deteksi Berbasis DNA Spesifik Spesies Dalam Autentikasi Produk Halal. INFOPOM. Vol 18 Nomor 1: 3-4 

halal+MUI [diakses tanggal 28 Juni 2017]
"Brosur
Pork Detection
Kit
(Porcine Test
E Catalogue)".
https://ekatalog.lkpp.go.id/backend/produk/download lampiran/104274 [diakses tanggal 29 Juni 2017]

Zulfahmi. 2015. Deteksi Kontaminan Babi Pada Produk Makanan Menggunakan Teknologi DNA Molekuler. Jurnal Penelitian Sosial Keagamaan. Vol. 18 Nomor 1: 1-6

Vivikananda, E. 2014. Deteksi DNA Babi dan DNA Sapi Dengan Menggunakan Metode Insulated Isothermal Polymerase Chain Reaction (ii-PCR). Skripsi Program Studi Farmasi UIN Syarif Hidayatullah Jakarta. 4-20

Najiha, A.A., Tajul, A.Y., Norziah, M.H., and Nadiah, W.A.W. 2010. A Preliminary Study on Halal Limits for Ethanol Content in Food Products. Middle-East Joumal of Scientific Research 6 (1): $45-50$ 